Annals of Plant Sciences

ISSN: 2287-688X

OPEN ACCESS

www.annalsofplantsciences.com

Research Article

\title{
Susceptibility of Pericopsis elata (Assamela) to heartwood decay and identification of micro and macro fungi associated with the disease in Cameroon
}

Djeugap Fovo Joseph ${ }^{1 *}$, Ngoune Djouke Patrick Francky ${ }^{1,2}$, Ntabe Ngbanye Eric ${ }^{3}$, Gweth Likaa René Samuel ${ }^{4}$

${ }_{1}^{1}$ Plant Pathology and Agricultural Zoology Research Unit, Department of Plant Protection, Faculty of Agronomy and Agricultural Science (PO Box 222 Dschang), University of Dschang, Cameroon.

${ }^{2}$ Sylviculture Laboratory, Department of Forestry, Faculty of Agronomy and Agricultural Science (PO Box 222 Dschang), University of Dschang, Cameroon.

${ }^{3}$ Department of Civil Engineering and Forestry Techniques, Higher Technical Teachers' Training College (HTTTC), Kumba, University of Buea (PO Box 63 Buea), Cameroon.

${ }^{4}$ Society of Forestry and Agricultural Exploitation of Cameroon (PO Box 9142 Douala), Cameroon.

Received: 9/17/2017; Revised: 9/23/2017; Accepted: 10/18/2017.

\begin{abstract}
Heartwood decay is one of the major pathological constraints affecting the quality and marketable volume of tropical timber. A study on its behavior was conducted on Pericopsis elata in order to contribute to its sustainable management in Cameroon. Tree susceptibility to heartwood decay was evaluated using three diameter classes, based on allometric equations between decayed and healthy trees. Wood samples and visible macromycetes were taken from living and felled trees with an auger. Isolation of microfungi was performed on potato dextrose agar medium and their identification was based on the morphological and microscopic characteristics of the mycelium and conidia with reference to identification keys of mycology. Identification of macromycetes was based on their morphological characteristics as described in reference books on macromycetes identification. Results show that diameter class ]110, 120[ presented highly significant $(\mathrm{P}<0.05)$ volume loss $\left(3755.96 \mathrm{~cm}^{3}\right)$, followed by diameter class ]100, 110[. Microfungi frequently associated with heartwood decay of P. elata were Cercospora sp (24.57\%), Fusarium oxysporum (12.64\%) and Penicillium sp (12.58\%) in living decay trees and Aspergillus niger (25.19\%), Cercospora sp (22.21\%), Penicillium sp (17.69\%) and Phoma sp (15.05\%) in felled decay trees. Macrofungi associated with living trees were Inonotus sp and Ganoderma sp. This is the first time that these fungal species are reported on P. elata wood. This study provides baseline information for the study of heartwood decay and management of $P$. elata in Cameroon.
\end{abstract}

Keywords: Heartwood decay; Macrofungi; Microfungi; Diameter class, Pericopsis elata; Wood loss.

\section{Introduction}

The Congo Basin forests represent a rich floristic diversity thatneeds to be managed sustainably. Logging constitutes a vibrant economic activity for the financial performance of governments and forest companies (Belinga, 2009). In Cameroon, Pericopsis elata (Harms) Meeuwen (Fabaceae family) which has as trade name Assamela or Afrormosia is an economically important timber species. It isclassified by the International Union for the Conservation of Nature (IUCN) as an endangered species (Bourland et al., 2010). Since 2005, the International Tropical Timber Organization (ITTO) and the Convention on International Trade in Endangered Species of Wild Fauna and Flora (CITES) have been working together to develop a broad capacity-building project for countries on the sustainable trade of this species. It is limited in distribution (Betti, 2008; Ouédraogo, 2014 ) and its exploitation is confronted with biotic constraints such as its natural regeneration and susceptibility to heartwood decay. Pericopsis elata is a valuable timber species in the world tropical timber market due to its varied uses (ITTO, 2007). In Cameroon, a cubic meter is 252 US \$ (Ambara, 2009; MINFI, 2009) and the felling tax in zone 3 of the country (East Region) according to decree $\mathrm{N}^{\circ}$ $000533 / \mathrm{CF} / \mathrm{A} / \mathrm{MINFI} / \mathrm{DGD}$ of $02 / 09 / 2016$ is 6 US $\$$ per cubic meter. The ITTO/CITES Workshop on Timber Trade in Afrormosia which held in Cameroon (Kribi) in 2008 was one of the most important steps for the establishment of the basis of sustainable management of the species. During this workshop, forest companies representing the timber industry raised, among other concerns, the need for its systematic regeneration, a review of its minimum exploitable diameter $(100 \mathrm{~cm})$ and heartwood decay problem. In Cameroon and within the Congo basin, the

\section{*Corresponding Author:}

Dr. Djeugap Fovo Joseph,

Senior Lecturer/Researcher, Ph.D (Université Laval, Québec, Canada),

Plant Pathologist,

Head of Plant Pathology and Agricultural Zoology Research Unit,

Department of Plant Protection,

Faculty of Agronomy and Agricultural Science,

University of Dschang, Republic of Cameroon.

E-mail: joseph.djeugap@,univ-dschang.org 
productivity of $P$. elata is confronted with heartwood decay, which results in significant though undetermined wood fibre and financial losses. Heartwood decay is an enzymatic alteration of wood by fungi capable of producing various enzymes for wood polysaccharide destruction such as cellulases, which degrade cellulose and oxidases that degrade lignin (Lekounoungou, 2008; Durand and Simard, 2011). For conservation measures, Cameroon sets the minimum exploitable diameter (MED) of P. elata at $100 \mathrm{~cm}$ (Amougou et al., 2009). Due to the relationship between the Minimum Exploitable Diameter (MED) of the species, heartwood decay and senescence, MED has to be re-evaluated based on scientific data. Due to the numerous biotic threats (low natural regeneration, heartwood rot and decrease in stand density), against insufficient data on its sustainable management and restricted knowledge about the heartwood decay of P. elata (Belinga, 2009), this study was embarked upon to identify mycetes that are associated with the heartwood decay of the species. It is envisaged that the results will provide additinal knowledge that can be used in prescribing a better management strategy for the species.

\section{Materials and Methods}

\section{Study area and sampling}

Samples of wood decay and visible macromycetes on tree trunks were collected from April to May 2016, using a simple random sampling design, in an annual cutblock of concession 10-010 (66,688ha), owned by SEFAC (Société d'Exploitation Forestière et Agricole du Cameroun) group. The concession is found in Libongo, Moloundou Sub-division of Boumba and Ngoko Division of the East Region of Cameroon. Specifically, it is located between latitudes $2^{\circ} \quad 30^{\prime} 08^{\prime \prime}$ and $2^{\circ} \quad 47^{\prime} 14^{\prime \prime}$ North and longitudes $15^{\circ} 36^{\prime} 00^{\prime \prime}$ and $16^{\circ} 01^{\prime} 10^{\prime \prime}$ East. Samples on symptoms of heartwood decay were collected both from standing and fallen trees. A random data collection by diameter class was carried-out on the trees. Infected tree cores as well as visible fruiting bodies of macromycetes were collected with a manual auger and introduced into plastic sachets that were labeled by type (living or felled trees) and taken to the laboratory for culture and identification of fungi.

Culture, isolation and identification of micro and macromycetes

Tree cores were disinfected in a $2 \%$ sodium hypochlorite solution for 5 minutes, followed by a triple rinse with sterilized distilled water and thereafter, the fragments were deposited on Hydrophilic paper to absorb excess water. Small core fragments were aseptically introduced into sterilized Petri dishes containing potato dextrose agar medium, in 4 replicates per type of lesion. The Petri dishes were then sealed and incubated at $21^{\circ} \mathrm{C}$ (Djeugap et al., 2017a). After the development of microscopic fungi around the decayed wood fragments, they were purified and identified based on their morphological characteristics using identification keys in mycology (Barnett and Hunter, 1972; Champion, 1997; Warharm et al., 2008). During isolation, the frequency of occurrence (FO) of each fungus was computed using the following formula: $\mathrm{FO}=(\mathrm{NF} / \mathrm{NT}) \times 100$, where $\mathrm{NF}=$ Highest number of samples from which a particular fungus was isolated, NT $=$ Total number of samples from which isolations were carried out (Iqbal and Saeed, 2012). Identification of macromycetes was based on the morphological characteristics of their carpophores with respect to the identification keys available in related literature (Camaioni, 1989; Courtecuisses and Duhem, 2007).

\section{Determination of wood loss volume by} diameter class

Allometric parameters such as tree diameter and wood length, and disease parameters such as decay diameter and decay depth were used to estimate the initial wood volume $\left(\mathrm{V}_{\mathrm{i}}\right)$ and the wood loss volume $\left(V_{o}\right)$ based on the following equations developed by the French National Organization for Standardization (Cailliez, 1980; AFNOR, 1985):

$\mathrm{V}_{\mathrm{i}}=\pi \mathrm{L}\left[\mathrm{d}_{\mathrm{o}}^{2}+\left(\mathrm{d}_{\mathrm{o}} \mathrm{xd}_{\mathrm{i}}\right)+\mathrm{d}_{\mathrm{i}}^{2}\right] / 12$, where $\mathrm{L}=\log$ length, $\mathrm{d}_{\mathrm{o}}=\mathrm{Log}$ diameter at the base and $\mathrm{d}_{\mathrm{i}}=\log$ diameter at small-end. $\mathrm{V}_{\mathrm{o}}=\left(\pi \mathrm{d}_{\mathrm{i}}^{2}\right) \mathrm{D} / 4$, Where $\mathrm{D}=$ Wood decay depth and $\mathrm{d}_{\mathrm{i}}=$ Log diameter.

For each diameter class, data was collected from 10 randomly selected individuals in a cutblock of concession 10-010. The difference between the two volumes $\left(\mathrm{V}_{\mathrm{i}}-\mathrm{V}_{\mathrm{o}}\right)$ was calculated to obtain the useful or merchantable timber volume $(\mathrm{Vu})$. Collected data was grouped into three diameter classes, ]90-100], ]100-110] and ]110-120] cm. Sensitivity to heartwood decay was assessed based on a study of the correlation between heartwood diameter $(\mathrm{x})$ and tree diameter (y). The Pearson's correlation coefficient ( $r$ ) between the two variables $x$ and $y$ was calculated by dividing the covariance of the variables by the product of their standard deviation. It is a statistical index that expresses the linear relationship between two quantitative variables and helps to predict a variable by another using a linear model (Artusi et al., 2002).

\section{Data analysis}

Data was collected on the initial wood volume, wood lost, merchantable volume and the isolation frequencies of the fungi. The data was subjected to analysis of variance and data in percent (isolation frequency) was previously transformed (arcsin) before being subjected to statistical analysis. SAS version 9.1 software was used for the analysis and the means were separated using Duncan's multiple separation tests at $5 \%$ probability. 


\section{Results}

Identification and description of micromycetes associated with $P$. elata wood

Several microscopic fungi were identified on infected wood fragments of $P$. elata trees on both standing and felled trees. The most frequently identified microscopic fungi were Cercospora sp (24.57\%) and Aspergillus niger (25.19\%) in standing or living trees and Cercopora sp (22.21\%) in felled trees (Table 1). The least identified was Trichoderma barzianum (4.18\%). Microscopic fungi like Colletotrichum sp, Fusarium oxysporum and T. harzianum were absent in felled trees. The fungal colony on culture medium and microscopic characteristics of mycelium and conidia are shown on Figure 1. The physical aspect of both mycelium and conidia varied from one fungal species to another. After 14 days of culture on PDA medium, mycelium of $A$. flavus turned greenish and purplish when mature while $A$. niger was black, Cercospora sp and Rhizoctonia sp were greyish, Colletotrichum sp, Phoma sp and Phomopsis salicina were whitish and Trichoderma harzianum was green. The conidia size (morphology) and the number of cells per conidia also varied from one species to another (Figure 1).

Table 1. Isolation frequencies of microfungi associated with heartwood decay of $P$. elata.

\begin{tabular}{lcc}
\hline \multirow{2}{*}{ Microfungi } & \multicolumn{2}{c}{ Isolation frequencies* (\%) } \\
\cline { 2 - 3 } & Living trees & Felled trees \\
\hline Aspergillus flavus & $6.91^{\mathrm{c}^{*}}$ & $11.09^{\mathrm{b}^{*}}$ \\
Aspergillus niger & $9.20^{\mathrm{c}}$ & $25.19^{\mathrm{a}}$ \\
Cercospora $\mathrm{sp}$ & $24.57^{\mathrm{a}}$ & $22.21^{\mathrm{a}}$ \\
Colletotrichum $\mathrm{sp}$ & $7.97^{\mathrm{c}}$ & $0^{\mathrm{d}}$ \\
Fusarium oxysporum & $12.64^{\mathrm{b}}$ & $0^{\mathrm{d}}$ \\
Penicillium $\mathrm{sp}$ & $12.58^{\mathrm{b}}$ & $17.69^{\mathrm{b}}$ \\
Phoma sp & $7.41^{\mathrm{c}}$ & $15.05^{\mathrm{b}}$ \\
Phomopsis salicina & $6.10^{\mathrm{c}}$ & $4.17^{\mathrm{c}}$ \\
Rhizoctonia solani & $8.43^{\mathrm{c}}$ & $4.6^{\mathrm{c}}$ \\
Trichoderma harzianum & $4.18^{\mathrm{c}}$ & $0^{\mathrm{d}}$ \\
\hline
\end{tabular}

*Means with the same letter in the column are not significantly different using the Duncan multiple range test at $5 \%$.

Table 2. Healthy and decay wood volumes of Pericopsis elata by diameter class.

\begin{tabular}{lccc}
\hline $\begin{array}{l}\text { Class diameter } \\
(\mathbf{c m})\end{array}$ & Initial wood volume $\left(\mathbf{c m}^{3}\right)$ & $\begin{array}{c}\text { Healthy wood volume } \\
\left(\mathbf{c m}^{3}\right)\end{array}$ & Wood decay volume $\left(\mathbf{c m}^{3}\right)$ \\
\hline$] 90-100]$ & $31409.82 \pm 761.85^{\mathrm{b}}$ & $31035.31 \pm 442.68^{\mathrm{a}}$ & $374.52 \pm 34.6^{\mathrm{c}}$ \\
{$[100-110]$} & $40474.87 \pm 832.77^{\mathrm{b}}$ & $38548.26 \pm 276.12^{\mathrm{a}}$ & $1926.61 \pm 128.7^{\mathrm{b}}$ \\
{$[110-120]$} & $58170.49 \pm 893.41^{\mathrm{a}}$ & $45414.53 \pm 678.01^{\mathrm{a}}$ & $3755.96 \pm 221.73^{\mathrm{a}}$ \\
\hline
\end{tabular}

${ }^{*}$ Means with the same letter in the column are not significantly different using the Duncan multiple range test at $5 \%$.

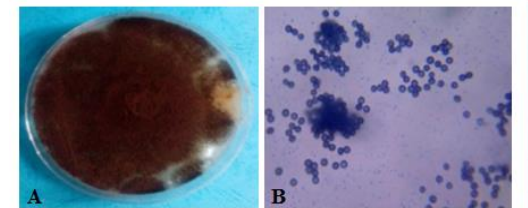

Aspergillus flavus

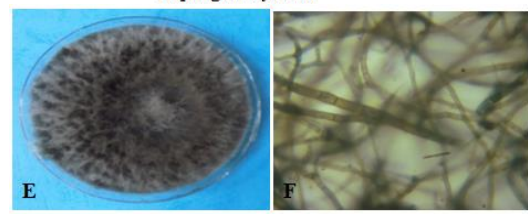

Cercospora sp

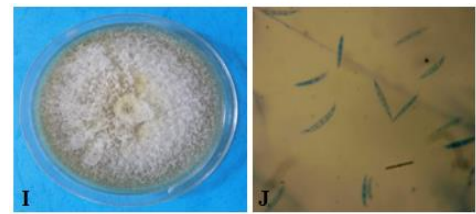

Fusarium $s p$

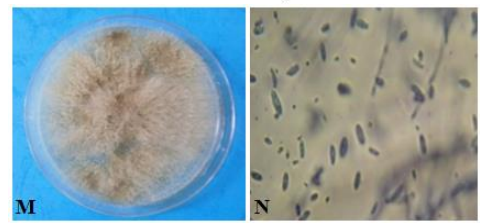

Phoma sp

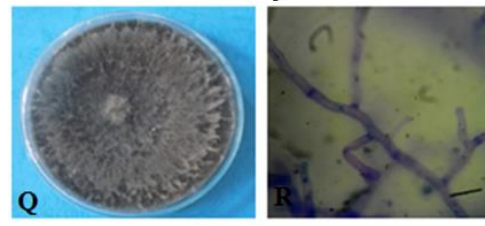

Rhizoctonia sp

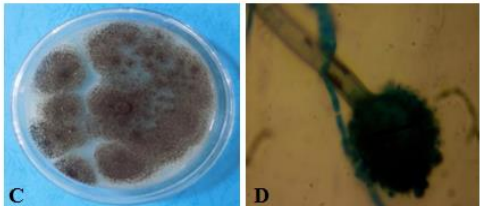

Aspergillus niger

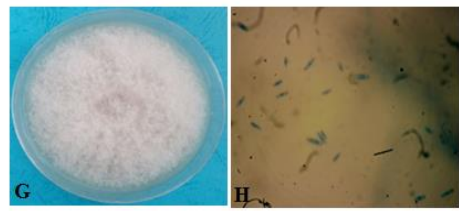

Colletotrichum $s p$

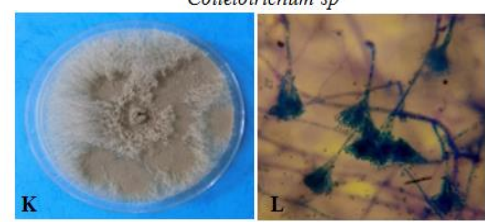

Penicillium $\mathrm{sp}$

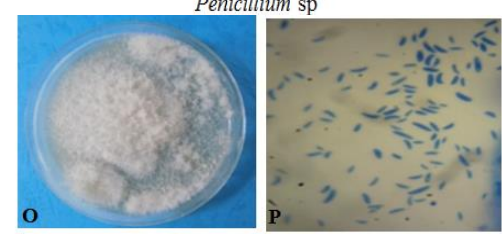

Phomopsis salicina

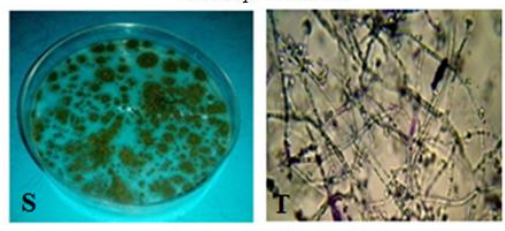

Trichoderma harzianum

Figure 1. Pure culture in Petri dishes, mycelium and conidia of microfungi associated with heartwood decay of $P$. elata after 14 days of culture. 

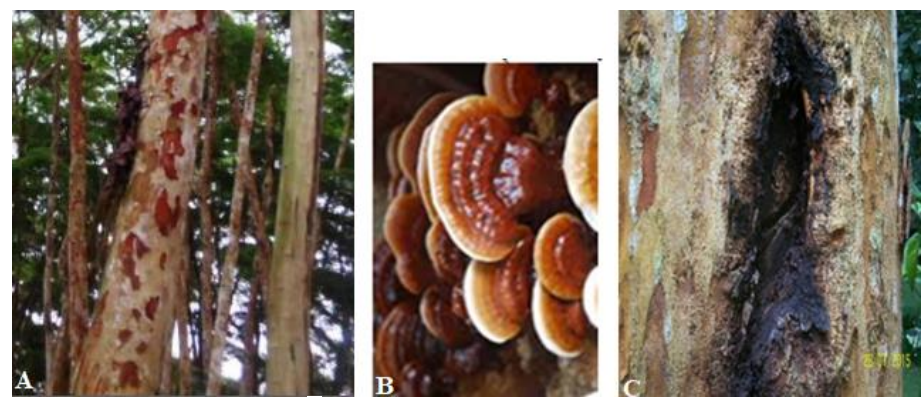

Figure 2. Fruiting bodies of macromycetes Ganoderma sp. (A and B) and senescent fruiting bodies of Inonotus sp. (C) on the trunk of P. elata.

\section{Description of the macromycetes identified on} Pericopsis elata wood

The macromycetes identified on P. elata wood were Ganoderma sp and Inonotus sp. On P. elata wood, Ganoderma sp has the appearance of varnished wood of reddish brown color and honey. The carpophore is thick, tough, rounded and slightly wrinkled radially with margins covered with a whitish pruin. Inonotus sp presents itself in the form of a soft and fleshy mass to touch, yellowish to golden, without the hymenal layer and becoming grayish in the internal parts disintegrating into a mass of chlamydospores (Figure 2).

\section{Evaluation of impact of heartwood decay by diameter class}

Highly significant $(\mathrm{P} \leq 0.05)$ wood volume loss was obtained from individuals within diameter class] 110,120 [ followed by individuals within diameter class $] 100,110[$. The lowest wood volume loss was obtained from individuals within diameter class ]90,100[. No significant difference $(\mathrm{P}>0.05)$ was observed in merchantable wood volume among the three diameter classes that were investigated (Table 2).

\section{Discussion}

This study reveals that several micro fungi and two macro fungi are associated with heartwood decay of $P$. elata both on standing and felled trees. Based on literature review, most isolated micromycetes would be endophytic, molds or parasitic fungi on forest trees or wood. For example, the species Fusarium oxysporum cause Fusarium wilt, a common and lethal disease of Albizia julibrissin in the USA (Stipes, 1999), dieback disease symptoms on Acacia koa in Hawaii (James et al., 2007). It was reported that Fusarium spp. and Penicillium spp. are superficial wood colonizing fungi; which first became noticeable as green, yellow, brown, or black, fuzzy or powdery surface growths on the wood surface (Kaarik, 1980). The species T. harzianum was reported as responsible for primary staining and superficial discoloration of wood which becomes bluish and blacken (Colling, 2002; Smith et al., 1979); the species is also known to be responsible for weight loss of holocellulose in intermediate and well decayed wood in Japan (Yu et al., 2011). On open pored hardwoods however, these molds may cause stains too deep to be easily removed. However, molds do not reduce the wood strength, but they can increase the capacity of wood to absorb moisture, thus increasing the potential of attack by decay fungi (Zabel and Morrell, 2012). Wood discoloration/staining observed in P. elata could be due to these fungi. Further studies should be conducted to confirm or deny their responsibility for the coloring of $P$. elata wood. The high moisture conditions in the forest where samples were collected (humid bimodal rainfall forest zone) could also favor wood colonization by these molds. Indeed, it is clearly established that moisture promotes mold growth (Johansson, 2012). However, the species belonging to the mold groups do not participate in wood degradation, but their presence on the wood surface either accelerates wood decomposition or creates favorable conditions for wood degradation fungi (Colling, 2002; Marthur and Olga, 2003). Given the that some of these molds produce mycotoxins on foodstuff (Colling, 2002; Okigbo and Osuinde, 2003; Abras et al., 2008; Djeugap et al., 2017b), it would be necessary to test their capacity to secrete toxic metabolites in P. elata wood in order to take appropriate biosafety measures by employees during logging and wood processing. The species Colletotrichum sp and Cercospora sp are generally found on tree leaves where they cause anthracnosis and leaf spot respectively (Douglas, 2009). Some species of the genus Phomopsis sp have been shown to be directly involved in wood decay. Phomopsis sp was reported as wood decay fungus on the trunk of almond trees in Spain (Gramaje et al., 2012) and as pathogenic on almond trees in Portugal (Diogo et al., 2010). Moreover, Abras et al., (2008) show that $P$. salicina provokes necrosis and gray, brown circular necrosis which favors wood rot in willows in Wallonia. Therefore, Phomospis salicina could be associated with heartwood decay both in standing and felled trees of P. elata.

Macromycetes Inonotus sp and Ganoderma sp. identified on the trunks of $P$. elata had been reported in previous studies as true wood decomposition Basidiomycetes. Indeed, these wood decay fungi have a set of degradation enzymes (oxidases, cellulases) which degrade lignin and 
cellulose. The species Inonotus rickii, I. hispidus and I. dryophilus were reported as the causal agents of canker, wood decay and white rot in various tropical hardwoods (Binion et al., 2008). It was the same with Ganoderma applanatum, G. lucidum causing white stem rot and root rot in Acacia confusa and Ficus macrocarpa in China (Melo et al., 2002; Dai et al., 2007). However, the rate of decomposition of these polysaccharides varies widely, depending on the fungal species and environmental conditions within the wood (Abras et al., 2008). It is the first time that these fungal species are reported on P. elata wood.

The study also shows that heartwood decay causes wood losses of $3755.96 \mathrm{~cm}^{3}$ in P. elata. This volume is high for only 30 trees sampled in the Annualcutblock (ACB 4-1) where the study was carried out. It was observed that heartwood decay in P. elata increases with increase in diameter class. This could be explained by the fact that the tree loses its ability to defend itself naturally against wood decay fungi with age. Although the tree has various natural defense mechanisms during active growth such as anatomical barriers, biochemical molecules (phytoanticipin and phytoalexin) and compartmentalization of decay in trees (Shigo and Tippett, 1981, Pearce, 1996), it loses the ability to produce defense tools with age and becomes vulnerable to wood decay fungi. It would therefore be wise to extend the study to all other ACB of the SEFAC group forest concessions (10-008, 10-009, $10-012,10-064)$ in order to have complete estimates of the wood loss volume resulting from heartwood decay fungi in the concessions.

Heartwood decay has negative impacts on timber yield of the species. On the other hand, it was noted that individuals belonging to the diameter class] 110-120] recorded the highest wood loss volume and these losses gradually decreased as the diameter class decreased to ]90-100]. This variation shows that wood decay increases with senescence of the tree. It also suggests reduction of the minimum exploitable diameter (MED) of $P$. elata by the Cameroon government to $90 \mathrm{~cm}$. Indeed, Bourland et al. (2012) raise the ambiguity between MED of the species, tree senescence and heartwood decay. From this point of view, it would be preferable to harvest wood with a low MED and a high volume of healthy wood than an aging wood (with high MED) with low volume of healthy wood.

\section{Conclusion}

The objective of this work was to contribute to the improvement of the management of $P$. elata through the identification of mycetes associated with heartwood decay of the species. In Cameroon forests, $P$. elata is colonized both by micro and macromycetes which are responsible for a total wood loss volume of $3755.96 \mathrm{~cm}^{3}$ in individuals within a diameter class ranging from 110 to $120 \mathrm{~cm}$.
The volume of decayed wood increases with increase in diameter class. Micromycetes frequently associated with the disease were Cercospora sp, Fusarium oxysporum and Penicillium sp for standing trees and Aspergillus niger and Cercospora sp for felled trees. Wood discoloration fungi identified were Phomopsis salicina and Trichoderma harzianum while wood decay fungi were Inonotussp and Ganoderma sp. It is necessary to complete their identification through the use of molecular biology tools.

\section{Acknowledgement}

This work is the result of a scientific collaboration between the Phytopathology and Agricultural Zoology Research Unit of the University of Dschang and the forestry company, SEFAC. The authors express their profound gratitude to the company for the funding they received.

\section{References}

1. Abras S, Fassotte C, Chandelier A, Cavelier M, Guide visuel des principales maladies et ravageurs des essences ligneuses des milieux rivulaires en Wallonie, 2008, 121p.

2. AFNOR, Norme française NF B 50-003. Bois: Nomenclature du bois. Tour Europe Cedex 792080 paris la défense, 1985, 110p.

3. Ambara J, Evaluation de la productivité des parcelles de Pericopsis elata (Assamela) et test de validité des tarifs de cubage des unités forestières d'aménagement 10.021 et 10.001-2-3-4. 2009, 12p.

4. Amougou A, Betti JL, Bindzi I, Bilong P, Tchatat M, Ndam N, Onana M, Mbarga N, Belinga J, Koulbout $\mathrm{D}$, Tieguhong J, Assembe S, Ensuring international trade on Pericopsis elata (Fabaceae) is notdetrimental to its conservation in the Congo basin. National Forestry Development Agency, Cameroon, 2009, $97 \mathrm{p}$.

5. Artusi R, Verderio P, Marubini E, Bravais-Pearson and Spearman correlation coefficients: meaning, test of hypothesis and confidence interval. The International Journal of Biological Markers, 2002, 17 (2): $148-151$

6. Barnett HL, Hunter BB, Illustrated genera of imperfect fungi, $3^{\text {td }}$ edition. Burgess Publishing Company, 1972, 200p.

7. Belinga SJ, Gestion durable de Pericopsis elata (Assamela) dans les forêts de production au Cameroun. Etude du potentiel. Projet OIBT/CITES sur la gestion durable de $P$. elata dans le bassin du Congo. Yaoundé, Cameroun, 2009, 41p.

8. Betti JL, Non detriment findings report on Pericopsis elata (Fabaceae) in Cameroon, NDF Workshop Case Study 2 (Mexico) www. 2008, 59p.

9. Binion DE, Stephenson SL, Roody WC, Burdsall HH, Vasilyeva LN, Miller OK, Macrofungi of oak. Morgantown, West Virginia University Press, 2008, 467p. 
10. Bourland N, Kouadio YL, Colinet G, Doucet J-L, Pericopsis elata (Harms) Meeuwen in the south-eastern part of Cameroon: ecological and pedological approaches to improve the management of an endangered commercial timber species. Int. For. Rev., 2010, 12(5), 111-119.

11. Bourland N, Quelques éléments de synthèse sur l'écologie de Pericopsiselataau Sud-est du Cameroun. Travail présenté à l'atelier OIBT/CITES dans le cadre du projet : s'assurer que le commerce international du bois de Pericopsiselata (Afrormosia ou Assamela) n'est pas préjudiciable à sa conservation, 2012, 6 p.

12. Cailliez F, Estimation des volumes et accroissement des peuplements forestiers avec référence particuliere aux forets tropicales. Vol. 1 - estimation des volumes. Centre Technique Forestier Tropical, France, 1980, 107p.

13. Camaioni $\mathrm{F}$, Les caractères d'identification des macromycètes, 1989, 226p.

14. Champion R, Identifier les champignons transmis par les semences. Techniques et pratiques. INRA, Paris, France, 1997, 398 p.

15. Colling C, Les champignons du bois, 2002, 10p.

16. Courtecuisses R, Duhem B, Guide des champignons de France et d'Europe. Collection Les guides du naturaliste, 2007, 476p.

17. Dai YC, Cui BK, Yuan HS, Li BD, Pathogenic wood-decaying fungi in China. Forest Pathology, 2007, 37:105-120.

18. Diogo ELF, Santos JM, Phillips AJL, Phylogeny, morphology and pathogenicity of Diaporthe and Phomopsis species on almond in Portugal. Fungal Diversity, 2010, 44: 107-115.

19. Djeugap FJ, Nzuta C, Temgoua LF, Kenmogne G, Tekam PM, Champignons pathogenes associés aux semences et effet des substrats sur la germination, la croissance et l'infection des plantules chez Pericopsiselata au Cameroun. Revue Scientifique et Technique Forêt et Environnement du Bassin du Congo, 2017a, $8: 28-38$.

20. Djeugap FJ, Wanjuki I, Zena DG, Harvey J, First report of Aflatoxin, Fumonisin and Zearalenone contamination on selected edible non- timber forest products in Cameroon. $5^{\text {th }}$ Life Science Conference, August 04-06, University of Dschang, Cameroon, Book of abstracts, 2017b, 65p.

21. Douglas SM, Common Diseases of Maple.The Connecticut Agricultural Experiment Station (www.ct.gov/caes), 2009, 7p.

22. Durand J, Simard S, Les champignons de carie. Ministère des Ressources naturelles et de la Faune Direction de la protection des forêts Québec, Canada, 2011, 30p.
23. Gramaje D, Agustí-Brisach C, Pérez-Sierra A, Moralejo E, Olmo D, Mostert L, Damm U, Armengol J, Fungal trunk pathogens associated with wood decay of almond trees on Mallorca (Spain). Persoonia, 2002, 28: 1-13.

24. Iqbal N, Saeed S. Isolation of mango quick decline fungi from mango bark beetle, Hypocryphalus mangiferae (Coleoptera: Scolytidae). The Journal of Animal Science, 2012, 22: 644 - 648.

25. James RL, Dudley RS, Yeh A, Colonization of diseased Acacia koatrees with Fusarium species. Forest Protection, 2007, 7(6): 1-8.

26. Johansson P, Critical Moisture Conditions for Mould Growth on Building Materials, Licentiate thesis, Avdelningen för Byggnadsfysik, Lunds universitet, 2012, 119p.

27. Kaarik A, Fungi causing sap stain in wood. The Swedish University of Agricultural Science, International Research Group on Wood Preservation, Stockholm, Sweden, 1980, 112 p.

28. Lekounougou S-T, Evaluation et Compréhension des Mécanismes fongiques impliqués dans la dégradation du boisUniversité Henri Poincaré, Nancy-I, 2008, 186p.

29. Marthur SB, Olga K, Common laboratory seed health testing methods for detecting fungi. Frederiksberg, Denmark, 2003, 425 p.

30. Melo I, Ramos P, Caetano MFF, First record of Inonotus rickii (Basidiomycetes, Hymenochaetaceae) in Portugal. Portugaliae Acto Biologica, 2002, 20: 265269.

31. MINFI (Ministère de l'Environnement et des Forêts), Arrêté No09/123/CF/A/MINFI du 17 Juillet 2009 fixant exceptionnellement les valeurs FOB des essences pour le deuxième semestre de l'exercice 2009, Yaoundé, Cameroun, 2009, 5p.

32. ITTO (International tropical timber organization), S'assurer que le commerce international du bois de l'Afrormosia n'est pas préjudiciable à sa conservation. Rapport de l'Atelier Régional sur le Commerce durable de Pericopsis elata, Kribi, Cameroun, 2007, 69p.

33. Ouédraogo DY, Fayolle A, Daïnou K, Demaret C, Bourland N, Lagoute P and Doucet JL, Enrichment of Logging Gaps with a High Conservation Value Species (Pericopsis elata) in a Central African Moist Forest. Forests, 2014, (5): 3031-3047.

34. Okigbo RN, Osuinde MI, Fungal leaf spot diseases of mango (Mangifera indica L.) in Southeastern Nigeria and biological control with Bacillus subtilis. Plant Protection Science, 2003, 39: 70-77.

35. Pearce RB, Antimicrobial defenses in the wood of living trees. New Phytologist, 1996, 132(2): 203-233. 
36. Shigo A, Tippett JT, Compartmentalization of American elm tissues infected by Ceratocystis ulmi. Plant Disease, 1981, 65: 715-718.

37. Smith KT, Blanchard RO, Shortle WC, Effect of spore load of Trichoderma harianum on woodinvading fungi and volume of discolored wood associated with wounds in Acer rubrum. Plant Dis. Reptr., 1979, 63: 1070-1071.

38. Stipes RJ, 1999. Fusarium wilt of trees. In: Shade Tree Wilt Diseases. CL Ash, ed. APS Press, St. Paul, MN, 1999, pp 165-169.

39. Warharm EJ, Butler LD, Sutton BC, Contrôle des semences de maïs et de blé. Guide de laboratoire. International Maize and Wheat Improvement Center, Lisboa, Mexico, 2008, 86p.
40. Yu F, Takashi O, Hiroshi T, Wood decomposing abilities of diverse lignicolous fungi on non-decayed and decayed beech wood. Mycologia, 2011, 103 (3) :474-482.

41. Zabel RA, Morrell JJ, Wood Microbiology: Decay and its prevention. Academic Press, San Diego, CA, 2012, 476p.

\section{Cite this article as:}

Djeugap Fovo Joseph, Ngoune Djouke Patrick Francky, Ntabe Ngbanye Eric, Gweth Likaa René Samuel. Susceptibility of Pericopsis elata (Assamela) to heartwood decay and identification of micro and macro fungi associated with the disease in Cameroon. Annals of Plant Sciences 6.11 (2017) pp. 1751-1757.

doi: http://dx.doi.org/10.21746/aps.2017.6.11.6

Source of support: Forestry company, SEFAC (Société d'Exploitation Forestière et Agricole du Cameroun).

Conflict of interest: Nil 